\title{
Rekrutmen Calon Anggota Legislatif PSI Sumatera Barat pada Pemilu Legislatif 2019
}

\author{
Mayoga Pratama, Suryanef \\ Program Studi Pendidikan Pancasila dan Kewarganegaraan \\ Universitas Negeri Padang \\ E-mail: mayogapratama97@gmail.com
}

\section{ABSTRAK}

Rekrutmen politik salah satu dari fungsi dari partai politik yang bertujuan untuk menyeleksi orang-orang untuk dapat mengisi jabatan-jabatan politik. Adanya pendekatan asal comot, tidak sesuai aturan formal yang dibuat serta melahirkan kandidat yang bermasalah merupakan alasan utama penelitian ini. Artikel ini bertujuan untuk mengeksplorasi pola rekrutmen yang dilakukan oleh PSI serta faktor-faktor yang dipertimbangkan dalam rekrutmen politik PSI Sumatera Barat. Sebagai partai politik baru yang mengikuti Pemilu 2019 PSI tentunya memiliki cara khusus dalam merekrut calon anggota legislatifnya. Penelitian ini menggunakan pendekatan kualitatif deskriptif dengan informan Pengurus Dewan Pengurus Wilayah PSI Sumbar, Calon Anggota Legislatif Partai Solidaritas Iindonesia DPRD Provinsi Sumbar, Caleg PSI DPRD Kabupaten/Kota yang dipilih secara purposive sampling. Data penelitian dikumpulkan dengan wawancara dan studi dokumentasi dengan menggunakan langkah - langkah pengolahan data kualitatif. Hasil penelitian menunjukkan pertama, pola rekrutmen yang dilakukan PSI Sumatera Barat terbuka secara formal namun dalam pelaksanaannya masih bersifat semi tertutup, seperti tidak konsistennya pelaksanaan prosedur rekrutmen yang telah ditetapkan. Kedua, faktor Faktor-faktor yang dipertimbangkan terhadap Caleg PSI adalah faktor latar belakang tidak cacat moral, motivasi, pengurus partai, serta anak-anak muda yang memiliki semangat anti korupsi dan anti intoleransi.

Kata Kunci: partai politik, rekrutmen politik, calon anggota legislatif

\section{ABSTRACT}

Political recruitment is one of the functions of political parties that aims to select people to fill political position. The existence of an old-fashioned approach, not in accordance with the formal rules made and giving birth to problematic candidates is the main reason for this research. This article aims to explore the patterns of recruitment carried out by the Indonesian Solidarity Party and the factors considered in the political recruitment of the Indonesian Solidarity Party in West Sumatra. As a new political party participating in the 2019 general election, the Indonesian Solidarity Party certainly has a special way of recruiting legislative candidates. This study uses a descriptive qualitative approach with informants from the Board of Governors of the West Sumatra Indonesian Solidarity Party, Candidates for Legislative Members of the Iindonesia Solidarity Party of the Regional 
420 | Rekrutmen calon..

People's Representative Assembly West Sumatra Province, Party of Solidarity Iindonesia Candidates for the Regional People's Representative Assembly Regency / City selected by purposive sampling. Research data were collected by interview and documentation study using qualitative data processing steps. The results showed that the recruitment pattern carried out by the Indonesian Solidarity Party of West Sumatra was formally open but in its implementation it was still semi-closed. While the factors that are considered against the Indonesian Solidarity Party Candidates are background factors with no moral defects, motivation, party officials, and young people who have anti-corruption and anti-intolerance zeal.

Keywords : political party, political recruitment, legislative candidates (C) (D) (9) This work is licensed under the Creative Commons Attribution-ShareAlike 4.0 International License. (22019
by author. 


\section{PENDAHULUAN}

Eksistensi suatu partai politik dapat dilihat dari bagaimana kemampuan suatu partai tersebut menjalankan fungsinya. Salah satu dari beberapa fungsi partai politik adalah rekrutmen politik. Menurut Suryanef (2005) rekrutmen politik pada dasarnya merupakan proses penyeleksian seseorang untuk dapat mengisi jabatan- jabatan politik pemerintahan. Penelitian mengenai rekrutmen calon anggota legislatif yang dilakukan oleh PSI Sumatera Barat penting dan menarik dikarenakan dalam rekrutmen politik yang dilaksanakan oleh partai politik dianggap buruk oleh masyarakat. Faktor-faktor di balik produk rekrutmen politik yang buruk ini adalah belum terbangunnya sistem rekrutmen politik yang baku, terbuka, demokratis, dan akuntabel di kalangan kebanyakan parpol di Indonesia. Sebagian parpol mendasarkan sumber rekrutmen politik dari lingkungan keluarga dan kerabat politik para elite parpol itu sendiri, sehingga cenderung berlangsung tertutup, ekslusif, dan nepotis serta diberlakukannya pemberian mahar politik oleh oknum partai politik.

Partai Solidaritas Indonesia atau disingkat PSI merupakan salah satu parpol yang baru di Indonesia yang didirikan pada tanggal 16
November 2016. PSI membawa corak baru dalam ideologi kepartaian di Indonesia, yang mana sebelumya didominasi oleh partaipartai yang mengedepankan ideologi nasionalisme dan agama. Partai ini berideologikan Pancasila \& pluralisme. Selain itu PSI dikatakan sebagai partai politik milenial yang dipelopori oleh anakanak muda dan menggunakan cara-cara modern dan transparan dengan menggunakan teknologi yang sedang berkembang dalam proses rekrutmen, promosi dan marketing politiknya. Rekrutmen calon anggota legislatif versi PSI memiliki keunikan tersendiri yakni dengan mengirimkan karya tulisan "Program Pemberantasan Korupsi" dan lampiran riwayat hidup serta memiliki tim seleksi bakal caleg yang independen. (Tim PSI, 2015).

Pada Pemilu DPRD 2019 PSI berhasil memenuhi kuota 100\%. Sumbar mendaftarkan sebanyak 655 Bacaleg. Berdasarkan keterangan dari Ari Prima dalam (Hariansinggalang, 2018), selaku ketua Dewan Pengurus Wilayah PSI Sumatera Barat menjelaskan untuk Bakal Calon Legislatif Sumatera Barat sejumlah 65 orang (100 persen). Ari mengatakan sesuai dengan arah gerak PSI sejak didirikan, juga dominan anak muda. Usia dibawah 35 tahun sebanyak 56 orang (76 persen) dan di atas 35 tahun 15 orang (24 
persen). Begitu pula untuk kuota 30 persen caleg perempuan, PSI Sumbar mendaftarkan 27 bacaleg perempuan (42 persen) dan bacaleg laki-laki 38 orang (58 persen). (https:// hariansinggalang.co.id/p enuhi-kota-100-persen-psi-sumbardaftarkan-655-bacaleg/). Artikel ini bertujuan untuk mengungkapkan bagaimana pola rektumen calon legislatif yang dilakukan Dewan Pengurus Wilayah PSI Sumatera Barat, apakah rekrutmen politik yang dilakukan bersifat terbuka atau tertutup dan faktor-faktor yang menentukan Dewan Pengurus Wilayah Paratai Solidaritas Indonesia Sumatera Barat dalam rekrutmen calon anggota legislatif.

\section{METODE PENELITIAN}

Penelitian ini merupakan jenis penelitian kualitatif. Pengambilan informan penelitian dilakukan dengan purposive sampling yang terdiri dari pengurus DPW PSI, Caleg DPRD Provinsi Sumbar dari PSI dan Caleg DPRD Kabupaten/Kota dari PSI. Penelitian dilakukan Kantor DPW PSI Sumatera Barat dan di beberapa wilayah di Sumatera Barat. Jenis data yang digunakan dalam penelitian ini adalah data primer dan data sekunder. Pengumpulan data dilakukan dengan wawancara tidak terstruktur, dan studi dokumentasi. Uji keabsahan data dengan menggunakan teknik trianggulasi data. Teknik analisis data dilakukan dengan tahapan pengumpulan data, reduksi data, penyajian data dan mengambil kesimpulan atau verifikasi data. Waktu observasi dan penelitian kurang lebih 3 bulan (Sugiyono, 2017).

\section{HASIL DAN PEMBAHASAN}

Pola Rekrutmen Calon Anggota Legislative PSI Sumatera Barat pada Pemilu Legislatif 2019

Pola rekrutmen adalah konstansi berbagai praktek rekrutmen oleh partai politik. Sungguhpun pada dasarnya setiap partai harus berprinsip untuk terbuka bagi kelompok sosial manapun, namun pada level parktis kerapkali sulit dihindari bahwa tiap kecenderungan tipe partai menstrukturkan perbedaan dalam menatap konsep rekrutmen yang dianggap ideal bagi partainya. Didalam negara yang menerapkan prinsip demokrasi serta dalam menghasilkan pemimpin yang berkualitas maka rekrutmen harus bersifat terbuka sebagaimana diungkapkan Gaffar (2005) bahwa untuk memperoleh pemimpin yang berkualitas rekrutmennya harus bersifat terbuka dan transparan. Selain itu Gaffar menjelaskan karakteristik dari rekrutmen politik adalah:

a. Mekanisme demokratis. 
b. Tingkat kompetensi politiknya sangat tinggi dan masyarakat akan mampu memilih pemimpin yang benar-benar mereka kehendaki.

c. Tingkat akuntabilitasnya pemimpinnya tinggi sehingga pada akhirnya melahirkan sebuah pemimpin yang demokratis dan mempunyai integritas yang tinggi.

PSI sebagai partai baru yang mengikuti Pemilu legislatif 2019 sudah mejalakan fungsinya sebagai sarana rekrutmen politik. Berdasarkan hasil wawancara dengan beberapa tokoh partai yang penulis anggap cukup mewakili rekrutmen yang dilakukan oleh PSI Sumatera Barat bahwasanya dalam perannya ini, PSI secara formal sudah melaksanakan rekrutmen politik seacara terbuka. Hal ini kurang lebih sesuai dengan yang dikemukakan oleh Syamsudin tentang indikator rekrutmen terbuka yang sesuai dengan karakteristik demokrasi, yaitu sebagai berikut:

a. Setiap warga negara dengan persyaratan tertentu memiliki kesempatan yang sama untuk dicalonkan. Dalam hal ini PSI telah membuka kesempatan seluasluasnya bagi seluruh masyarakat Indonesia

b. Pengambilan keputusan dilakukan dengan musyawarah dan mufakat. Berdasarkan data yang penulis dapatkan dari pengurus DPW PSI dalam menetapkan Daftar Caleg Sementara PSI memutuskan berdasarkan hasil rapat yang diikuti tim penyeleksi yang terdiri dari internal dan eksternal partai.

c. Punya aturan yang jelas. Di dalam melakukan rekrutmen perlu adanya aturan yang jelas dan formal terhadap siapa-siapa yang bisa direkrut. Dalam proses rekrutmen, PSI berpedoman pada SK DPP PSI nomor 581 Tahun 2017 tentang Prosedur Rekrutmen Calon Anggota Legislatif PSI dan persyaratan yang diumumkan secara terbuka di website resmi partai

d. Setiap warga negara yang dicalonkan mempunyai kewajiban yang sama. Setiap kandidat Calon Anggota Legislatif PSI secara formal juga harus melengkapai persyaratan yang sama yang nantinya juga akan diseleksi oleh tim yang sama, hanya saja pengurus partai mendapatkan nilai lebih secara moril karena dianggap sudah berjasa dalam kemajuan partai.

Sebagai partai baru, PSI di Sumatera Barat cukup baik dalam hal pemenuhan kuota caleg. Proses rekrutmen calon anggota legislatif dilaksanakan secara formal sebagaimana yang terdapat dalam SK DPP PSI nomor 581 Tahun 2017 
Lampiran IV tentang Timeline Caleg PSI. Berikut adalah tahapantahapan rekrutmen calon anggota legislatif yang dilaksanakan oleh PSI pada Pemilu 2019 berdasarkan hasil temuan penulis di lapangan. Pertama, tahap persiapan dilakukan untuk menetukan prosedur teknis formal yang berpedoman pada UU Pemilu yang dibuat oleh KPU dan AD/ ART partai serta peratuan terkait Pemilu lainnya.

Pada tahap ini juga dipersiapkan halaman online di setiap situs resmi pusat, wilayah maupun daerah diiringi dengan pembuatan atribut pendaftaran bacaleg. Pemasangan atribut ini dilakukan oleh Tim Bappilu yang dipipimpin oleh Korlap Bappilu dan juga Tim Bappilu mensosialisasikan pada seluruh tingkatan pengurus daerah. Tahapan ini dapat terlaksana dengan baik sesuai dengan perencanaan. Kedua, tahap Pendaftaran. Pada tahap pendaftaran setiap kandidat Bacaleg baik pengurus dan luar pengurus membawa berkas persyaratan sebagaimana tercantum di website resmi psi.id. Pada rekrutmen Caleg 2019 pendaftaran dibuka secara dua gelombang. Pada tahap administrasi tidak terlaksana dengan baik karena tidak dilengkapinya persyaratan pengiriman karya tulis ilmiah. Hal ini terjadi karena pertimbangan pemenuhan kuota Caleg sebanyak $100 \%$ serta pemenuhan keterwakilan perempuan sebanyak $30 \%$.

Ketiga, tahap Evaluasi Dokumen. Pada tahap ini evaluasi dokumen dilakukan oleh masingmasing tingkatan kepengurusan wilayah (DPW) dan DPD untuk daerah. Evaluasi dilakukan oleh tim yang terdiri dari pengurus pengurus, kelulusan tahapan administrasi ini diumumkan lewat Whattapps Group Bacaleg 2019. Keempat, tahap evaluasi kompetensi. Peserta lolos seleksi evaluasi dokumen mengikuti interview bersama joint committee. Wawancara pada tahap ini dilakukan oleh tim yang terdiri dari internal dan eksternal partai. Pada tahap perhitungan perhitungan nilai hasil interview bagi pengurus partai mendapat prioritas yang lebih daripada luar pengurus. Hasil keputusan evaluasi kompetensi diinformasikan kepada Bakal Calon Sementara Caleg PSI melalui Whatsapp Group Caleg PSI 2019. Kelima, Tahap Evaluasi Sosialisasi.

Bagi kandidat yang lolos wawancara, masing-masing diumumkan ke masyarakat dapilnya. Hal ini bertujuan untuk memberikan kesempatan masyarakat untuk memberikan 
pendapat atau laporan pada pengurus terhadap kandidat Caleg yang akan ditetapkan partai dari Bakal Calon Sementara (BCS) menjadi Daftar Caleg Sementara (DCS) .Hasil keputusan evaluasi sosialisasi kepada bakal calon cementara melalui Whatsapp Group Caleg PSI 2019. Keenam, Tahap Penetapan. Pada tahap Penetapan ini DCS (Daftar Caleg Sementara) yang nantinya akan diserahkan ke KPU untuk diverifikasi ulang dan ditetapkan sebagai DCT (Daftar Caleg Tetap) oleh KPU. Pada penetapan DCS di DPW kandidat caleg akan ditetentukan nomor urut di Dapilnya dengan mekanisme "cabut undian".

Dalam menganalisis hasil identifikasi, tahapan rekrutmen yang dilakukan bagaimana PSI Sumbar dalam mengorganisasikan partai politiknya. Dalam rekrutmen politik, penulis menggunakan empat hal penting yang dapat menunjukkan bagaimana pengorganisasian partai politik dalam rekrutmen politik yang terdapat dalam (Rahat dan Hazan, 2001), yaitu siapa kandidat yang dapat dinominasikan, siapa yang menyeleksi, dimana kandidat diseleksi, serta bagaimana kandidat diputuskan. Menurut Rahat dan Hazan (2001) yang dapat dinominasikan dalam rekrutmen politik dapat diklasifikasikan berdasarkan tingkat inklusifitas atau eksklusifitas. Terkait dengan penominasian ini PSI Sumatera Barat menerapkan model inklusif. Sebagaimana yang dikatakan Rahat dan Hazan (2001) dalam model inklusif, setiap pemilih dapat menjadi kandidat partai.

Pembatasnya hanya regulasi yang ditetapkan negara. Dalam hal ini PSI menetapkan kandidat yang dapat mengikuti rekrutmen tidak hanya pengurus partai tapi membuka peluang pada masyarakat seluas-luasnya. PSI juga mendasari proses rekrutmen yang dilakukannya pada aturan yang ditetapkan oleh KPU sebagai lembaga yang berwenang dalam Pemilu di Indonesia, hanya saja lebih lanjut dilanjutakan secara teknis dengan ketetapan yang dibuat oleh organisasi partai namun tidak merubah aturan yang mendasar.

Kemudian dalam mekanisme seleksi, menurut Rahat dan Hazan dalam (Syamsudin, 2001), penyeleksi dapat diklasifikasikan dalam sebuah kontinum, sama seperti kontinum kandidasi, berdasarkan tingkat inklusifitas dan eklusifitas. Pada titik ekstrim, penyeleksi adalah sangat inklusif, yaitu pemilih yang memiliki hak memilih dalam Pemilu. Dalam ekstrim yang lain, yaitu selektor sangat eklusif 
dimana kandidasi ditentukan oleh pimpinan partai. Dalam hal ini penyeleksi tim penyeleksi yang dibentuk oleh Partai Solidaritas Indonesia terdiri atas unsur inklusif yaitu masyarakat dan unsur eksklusif yaitu pengurus partai. Jadi, dapat dikatakan tim penyeleksi PSI bersifat semi atau gabungan dari keduannya.

Sementara itu Norris dan Lovenduski (1995) membagi agen pembuat keputusan dalam rekrutmen politik berdasarkan dua dimensi yaitu dimensi bagaimana kekuasaan disebarkan. Yaitu apakah kekuasaan tersentralisasi di pusat, regional atau local dan bagaimana formalisasi keputusan dibuat. Apakah dibuat secara formal atau informal. Disebut informal apabila tidak ada standar norma yang dibakukan dan terdapat sedikit aturan dan regulasi konstitusional yang mengikat dan disebut formal apabila terdapat standarisasi prosedur yang dibakukan dan diekplisitkan dalam proses rekrutmen. Berdasarkan temuan peneliti di lapangan terkait agen pembuat keputusan dan bagaimana kekuasaan terebut disebarkan pada tingkatan regional.

Dalam proses rekrutmen PSI, kekuasaan tidak hanya berada di pusat (DPP) tetapi didesentralisasikan ke tingkat wilayah (DPW) dan tingkat kabupaten/kota (DPD). Jadi, menurut dimensi pertama pembuat keputusan dalam proses rekrutmen PSI bersifat desentralisasi. Hal ini juga menjawab persoalan ketiga, yaitu dimana kandidat diseleksi. Sedangkan pada dimensi kedua mengenai formalisasi keputusan, keputuan dalam rekrutmen yang dilakukan PSI bersifat semi formal. Hal ini karena temuan penulis dilapangan yaitu selain kandidat yang diseleksi secara bermusyawarah, ada juga beberapa kandidat yang diseleksi diluar forum formal, seperti faktor kedekatan dan faktor non formal lainnya.

Sedangkan model proses seleksi yang digunakan PSI adalah formal terpusat dan formal terlokal. Sebagaimana yanng dikatakan Norris dan Lovenduski (1995) formal-terpusat dan formal regional yaitu eksekutif partai pusat dan regional memiliki otoritas konstitusional untuk memutuskan kandidat dan penempatannya. Akan tetapi dalam prakteknya beberapa hal yang sudah diatur secara formal tidak juga dilaksanakan dengan baik.

Menjelaskan persoalan terakhir untuk memahami seleksi kandidat dan bagaimana kandidat dinominasikan, Rahat dan Hazan menyebutkan dua model yang 
konfrontatif, yaitu model pemilihan vs penunjukan. Dalam sistem pemilihan, penominasian kandidat adalah melalui pemilihan diantara penyeleksi. Pada sistem pemilihan yang murni, semua kandidat diseleksi melalui prosedur pemilihan tanpa seorang penyeleksi pun dapat mengubah daftar komposisi. Sementara itu dalam sistem penunjukan, penentuan kandidat tanpa menggunakan pemilihan. Dalam sistem penunjukan murni, kandidat ditunjuk tanpa membutuhkan persetujuan oleh agensi partai yang lain kecuali penominasian oleh partai atau pemimpin partai.

Rahat (2010) mengusulkan untuk mempertimbangkan dua persepsi umum terkait dengan demokrasi. Pertama, persepsi positif tentang demokrasi yakni demokrasi sebagai sebuah sistem yang memungkinkan semua warga berpartisipasi dalam memilih di antara calon dan kelompok yang bersaing dan mengklaim paling mewakili kepentingan dan nilai mereka. Persepsi kedua yang harus diperhatikan dalam melihat sistem seleksi kandidat yang demokratis. Menurut Rahat, adalah terkait dengan pandangan 'negatif' tentang demokrasi. Gagasan 'negatif' tentang demokrasi ini menganggap segala bentuk kekuasaan adalah potensial terjadinya penyimpangan (korup).
Berdasarkan sudut pandang Rahat tersebut, PSI Sumatera Barat secara formal bahkan ketentuan teknis yang dibuat sudah bersifat Demokratis. PSI sudah melakukan usaha-usaha agar proses rekrutmen yang dilakukan bersifat demokratis dengan menetapkan prosedur yang bersifat demokratis sampai kepada hal ynag bersifat teknis. Sesuai dengan yang dikatakan Rahat, ketika kekuasaan pemilihan kandidat semakin disebarkan diantara sejumlah aktor politik yang berbeda-beda, semakin demokratis lah sistem tersebut karena akan menciptakan keseimbangan kekuasaan (check and balances). Akan tetapi sudah terdapat keseimbangan antara pihak inklusif dan eksklusif dalam proses rekrutmen namun praktek yang dilaksanakan yang masih terdapat hal-hal tidak sesuai dengan ketentuannya. Maka dengan kata lain rekrutmen yang dilakukan PSI di Sumatera Barat masih bersifat semi demokratis.

Faktorfaktor yang dipertimbangkan dalam Merekrut Calon Anggota Legislatif PSI Sumatera Barat pada Pemilu $\underline{\text { Legislatif } 2019}$

Buruknya persepsi masyarakat terhadap politik khususnya terhadap calon anggota legislatif disebabkan calon anggota legislatif yang ditawarkan partai 
politik dianggap tidak memiliki kualitas untuk menjadi representasi rakyat di dalam parlemen. Beberapa upaya telah dilakukan partai politik dalam merekrut calon anggota legislatif untuk mendapatkan kader-kader terbaik.

Czudnowski dalam Greenstein (1975) memberikan beberapa faktor penting yang mempengaruhi rekrutmen politik. Faktor-faktor ini dapat dijadikan pertimbangan partai politik dalam merekrut kandidat. PSI Sumatera Barat berdasarkan hasil temuan peneliti telah menentukan faktorfaktor dalam rekrutmen kadernya. Selain yang dikemukan Czudnowski, PSI Sumatera Barat juga memiliki faktor khusus. Beberapa faktor yang menentukan dalam menentukan rekrumen calon anggota lgislatif PSI Sumatera Barat adalah latar belakang social dan motivasi. Sedangkan faktor-faktor lain seperti tingkat pendidikan, pekerjaan, aktivitas awal dan aktivitas akhir menjadi faktor yang berpengaruh secara tidak langsung.

Latar belakang sosial dan motivasi menjadi faktor yang diutamakan PSI dalam rekrutmennya. Latar belakang seseorang yang menjadi kader PSI haruslah orang-orang yang belum pernah terjerat kasus hukum terutama yang berkaitan dengan kejahatan gender dan KKN. PSI juga mengutamakan orang-orang yang belum pernah terlibat partai politik sebelumnya. Pertimbangan khusus PSI adalah anak-anak muda. Hal ini sesuai dengan tagline PSI yaitu "Partainya anak muda". Sedangkan Pendidikan, pekerjaan dan aktivitas awal hanya menjadi faktor tidak langsung. Artinya ketiga faktor tersebut dianggap secara tidak langsung akan mempengaruhi latar belakang dan motivasi seseorang. Misalnya semakin tinggi pendidikan akan berpengaruh terhadap motivasi seseorang. Faktor perkerjaan dan latar belakang ekonomi seseorang tidak menjadi bahan pertimbangan. Hal ini karena PSI yang anti pungutan biaya serta biaya sosialisasi ke masyarakat dan atribut kampanye yang disediakan oleh pihak partai. Tetapi karena berbagai kendala yang dihadapi beberapa faktor ini terabaikan. Pada akhirnya banyak juga caleg yang berasal dari orang-orang yang sudah tua dan pernah terlibat partai politik lain.

\section{SIMPULAN}

Pola rekrutmen calon anggota legislatif PSI Sumatera Barat dilaksanakan secara terbuka. Meskipun secara prosedural formal pelaksanaan rekrutmen calon anggota legislatif sedah terbuka, namun dalam pelakasanaannya dilapangan masih bersifat semi tertutup. Hal ini terlihat dari 
prosedur formal rekrutmen yang dimiliki partai dan merekrut seluruh lapisan masyarakat, tetapi masih banyak inkonsistensi dalam pelaksanaan proses peneyeleksian, penetapan dan model rekrutmennya. Proses rekrutmen ini dilakukan dari tingkat DPD untuk calon anggota legislatif DPRD Kabupaten/ Kota. Tingkat DPW untuk calon anggota legislatif DPRD Provinsi dan untuk DPR RI dilaksanakan di DPP. Pada masingmasing tingkatnya proses rekrutmen dilakukan oleh tim penyeleksi yang terdiri dari internal dan eksternal partai yang kurang terlaksana dengan baik.

Model pengorganisasian Partai dalam pelaksanaan rekrutmen sebagain besar sudah bersifat demokratis. Hal ini dilihat dari penominasian kandidat yang bersifat inklusif, penyeleksi yang bersifat semi inklusif, agen pembuat keputusan dan bagaimana kekuasaan tersebut disebarkan pada tingkatan regional. Proses seleksi yang digunakan PSI adalah formal terpusat dan formal terlokal. Faktor-faktor yang dipertimbangkan terhadap caleg PSI adalah faktor latar belakang tidak cacat moral, motivasi, pengurus partai, serta anak-anak muda yang memiliki semangat anti korupsi dan anti intoleransi. Sedangkan faktor sosialisasi politik, aktivitas awal, tingkat pendidikan dan latar belakang pekerjaan dianggap sebagai faktor yang mempengaruhi secara tidak langsung.

\section{DAFTAR PUSTAKA}

Gaffar, Afan. 2005. Politik Indonesia Menuju Demokrasi. Yogyakarta: Pustaka Belajar Offset.

Greenstein, Fred I. \& Polsby, Nelson W. 1975. Handbook And Political Science.Vol. 2. Reading, Mass., AddisonWesley Pub. Co

Hariansinggalang. Penuhi Kuota 100 Persen, PSI Sumbar Daftarkan 655 Bacaleg. Edisi 18 Juli 2018.

Haris, Syamsudin, dkk. 2016. Panduan Rekrutmen \& Kaderisasi Partai Politik Ideal di Indonesia. Jakarta : Direktorat Pendidikan dan Pelayanan Masyarakat Kedeputian Pencegahan, Komisi Pemberantasan Korupsi Bekerja sama dengan Pusat penelitian Politik, Lembaga Ilmu Pengetahuan Indonesia (P2Politik LIPI).

Norris \& Lovenduski. 1995. Political Recruitment: Gender, Race and Class in the British Parliament. Cambridge: Cambridge University Press. 
430 | Rekrutmen calon..

Sugiyono. 2017. Metode Penelitian Kuantitatif, Kualitatif, dan R\&D. Bandung : Alfabeta.

Suryanef,dkk. 2005. Bahan Ajar Sistem Politik Indonesia. Padang: Fakultas Ilmu Sosial Universitas Negeri Padang.

Tim PSI. 2015. ABC Partai Solidaritas Indonesia. Jakarta. 